

\section{DISCLAIMER}

This report was prepared as an account of work sponsored by an agency of the United States Government. Neither the United States Government nor any agency Thereof, nor any of their employees, makes any warranty, express or implied, or assumes any legal liability or responsibility for the accuracy, completeness, or usefulness of any information, apparatus, product, or process disclosed, or represents that its use would not infringe privately owned rights. Reference herein to any specific commercial product, process, or service by trade name, trademark, manufacturer, or otherwise does not necessarily constitute or imply its endorsement, recommendation, or favoring by the United States Government or any agency thereof. The views and opinions of authors expressed herein do not necessarily state or reflect those of the United States Government or any agency thereof. 


\section{DISCLAIMER}

Portions of this document may be illegible in electronic image products. Images are produced from the best available original document. 
Reference to a company or product name does not imply approval or recommendation of the product by Union Carbide Corporation or the Department of Energy to the exclusion of others that may meet specifications.

Printed in the United States of America. Available from National Technical Information Service

U.S. Department of Commerce

5285 Port Royal Road, Springfield, Virginia 22161

Price: Printed Copy $\$ 4.00$; Microfiche $\$ 3.00$

This report was prepared as an account of work sponsored by an agency of the United States Government. Neither the United States Government nor any agency thereof, nor any of their employees, nor any of their contractors, subcontractors, or their employees, makes any warranty, express or implied, nor assumes any legal liability or responsibility for any third party's use or the results of such use of any information, apparatus, product or process disclosed in this report, nor represents that its use by such third party would not infringe privately owned rights. 
Distribution Category: UC-41

\title{
EVALUATION OF WASH BOTTLES FOR FLAMMABLE SOLVENT USE
}

\author{
C. R. Schmitt
}

H. D. Whitehear

Chemical Processes Department

Y-12 Development Division

J. E. White

Processing and Forming Operations Department Y-12 Metal Preparation Division

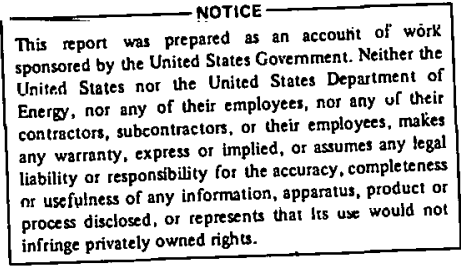

Oak Ridge Y-12 Plant

P. O. Box Y, Oak Ridge, Tennessee 37830

Prepared for the Department of Energy Under UE Coverament Contract W-7106-ong-36 


\section{ABSTRACT}

A study was made of the various types of containers that are used for dispensing flammatble solvents in the laboratory. One of the containers studied was modified and approved for dispensing flammable solvents. 
CONTENTS

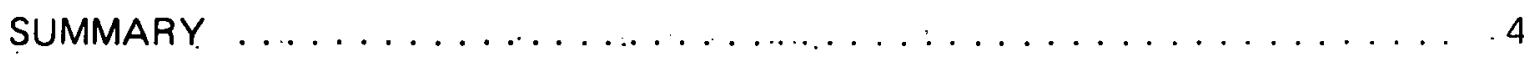

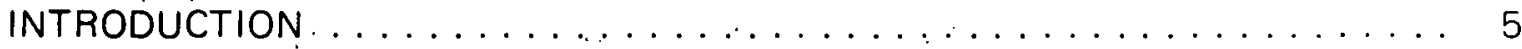

EVALUATING WASH BOTTLES CONTAINING FLAMMABLE LIQUIDS . . . . . . 6

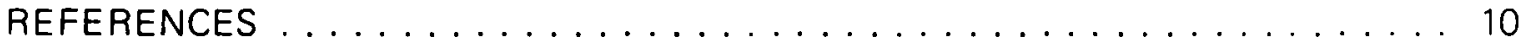




\section{SUMMARY}

Polyethylene wash bottles for flammable solvents were recently approved by the Department of Energy (DOE) for use at the Oak Ridge Y-12 Plant (a) with the restriction that pressure relief must be provided. A laboratory study was made of vent holes of various diameters located in the caps and dispensing tube of wash bottles containing a wide variety of flammable and nonflammable solvents. Wash bottles vented with a $0.63-\mathrm{mm}$ hole in the dispensing tube were found to be optimum for the needed pressure relief.

(a) Operated by the Union Carbide Corporation's Nuclear Division for the Department of Energy. 


\section{INTRODUCTION}

Small quantities of flammable liquids (less than one liter) are stored in most chemical laboratories, temporarily, on a shelf or workbench for convenience. Usually, rigid polyethylene or flexible polyethylene bottle containers (squeeze bottles) are used that are fitted with a polyethylene tube for convenient dispensing of the liquid contents. One problem associated with the use of such bottles containing flammable solvents is that they need to be vented to prevent any buildup of internal pressure, as might occur, for example, if a bottle were placed near a heat source. In addition, bottles containing flammable solvents with a high vapor pressure, as acetone or methanol, also have a tendency to drip liquid at the dispensing tip, thereby creating a potential fire hazard.

A study was needed to evaluate the utility and safety aspects of various types of available wash bottles for use with flammable solvents and to devise a satisfactory method for venting and labeling the solvents. 


\section{EVALUATING WASH BOTTLES CONTAINING FLAMMABLE LIQUIDS}

In two recent ORO-DOE fire-protection audits at the Oak Ridge Y-12 Plant, it was reported ${ }^{1}$ that the use of clear polyethylene laboratory-type wash bottles for dispensing small quantities of flammable liquids was a potential fire hazard, and it was recommended that Underwriters Laboratories (UL) or Factory Mutual (FM)-approved containers be obtained. Preliminary tests and evaluations were made on samples of all commercially available approved containers by the Plant Fire Protection Engineering Department. It was found that all of the approved containers were unsatisfactory in that they either leaked liquid due to the liquid's high vapor pressure, the same as the laboratory-type polyethylene wash bottles, or else they were too cumbersome for routine use.

Figure 1 is a photograph of various solvent dispensing bottles used at the Y-12 Plant. Referring to Figure 1, Dispensing Containers 1 and 3 are examples of "approved" containers which are made of red-pigmented, rigid, high-density polyethylene which have a spring-loaded brass valve for dispensing liquid contents. Containers 1 and 3 are examples of

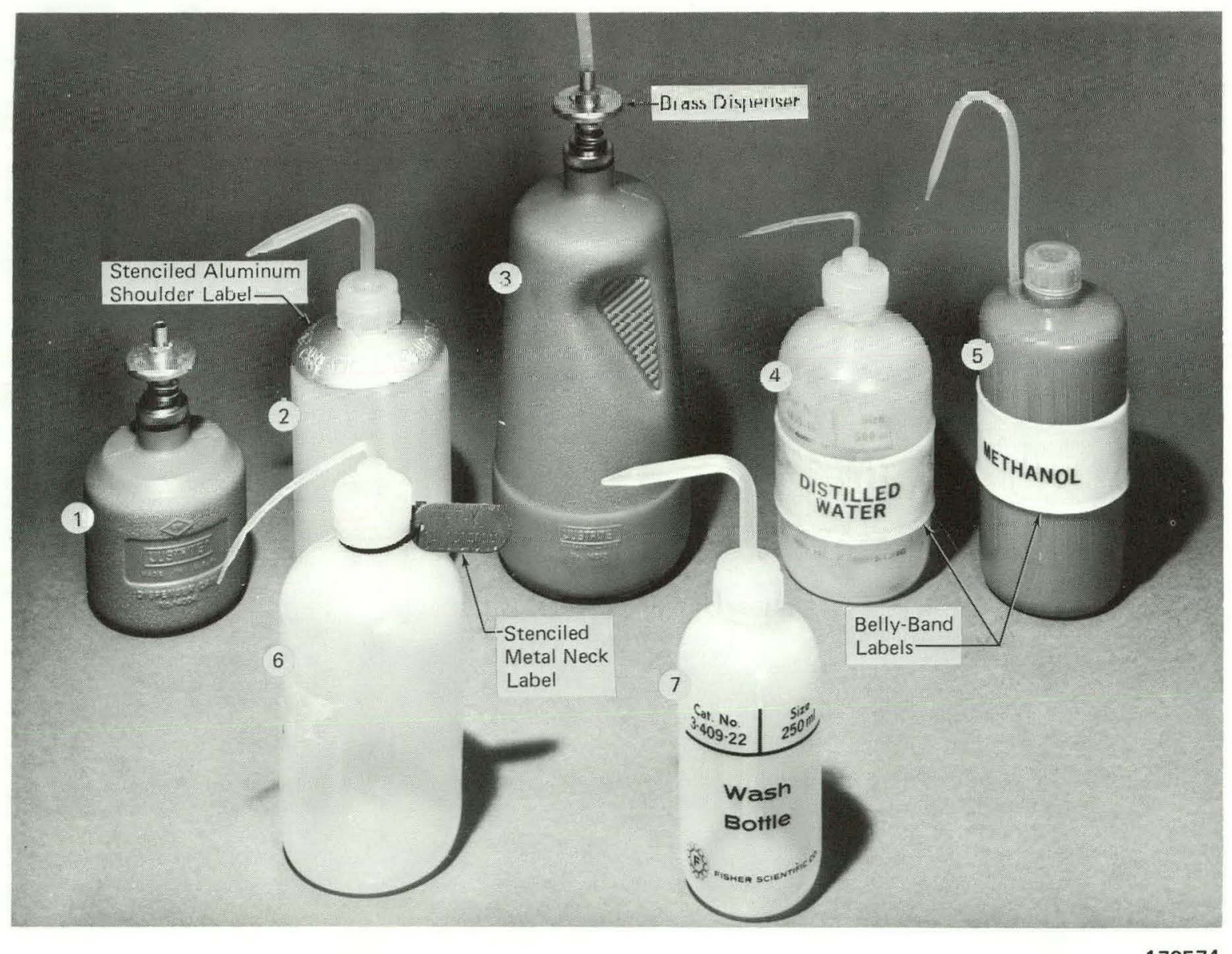

Figure 1. ASSORTED SOLVENT-DISPENSING BOTTLES IN USE AT THE Y-12 PLANT. (Shown are Various Methods of Identifying the Contents) 
those bottles that are relatively high in cost and are very cumbersome to use for dispensing small volumes of liquid. These containers also have metal dispensing components (brass) which could corrode or contribute metallic contamination when used with certain high-purity solvents.

Another type of commercially available flammable liquid dispensing container that was approved by ORO-DOE, UL, and FM is seen in Figure 2. Also shown is a 16-ounce

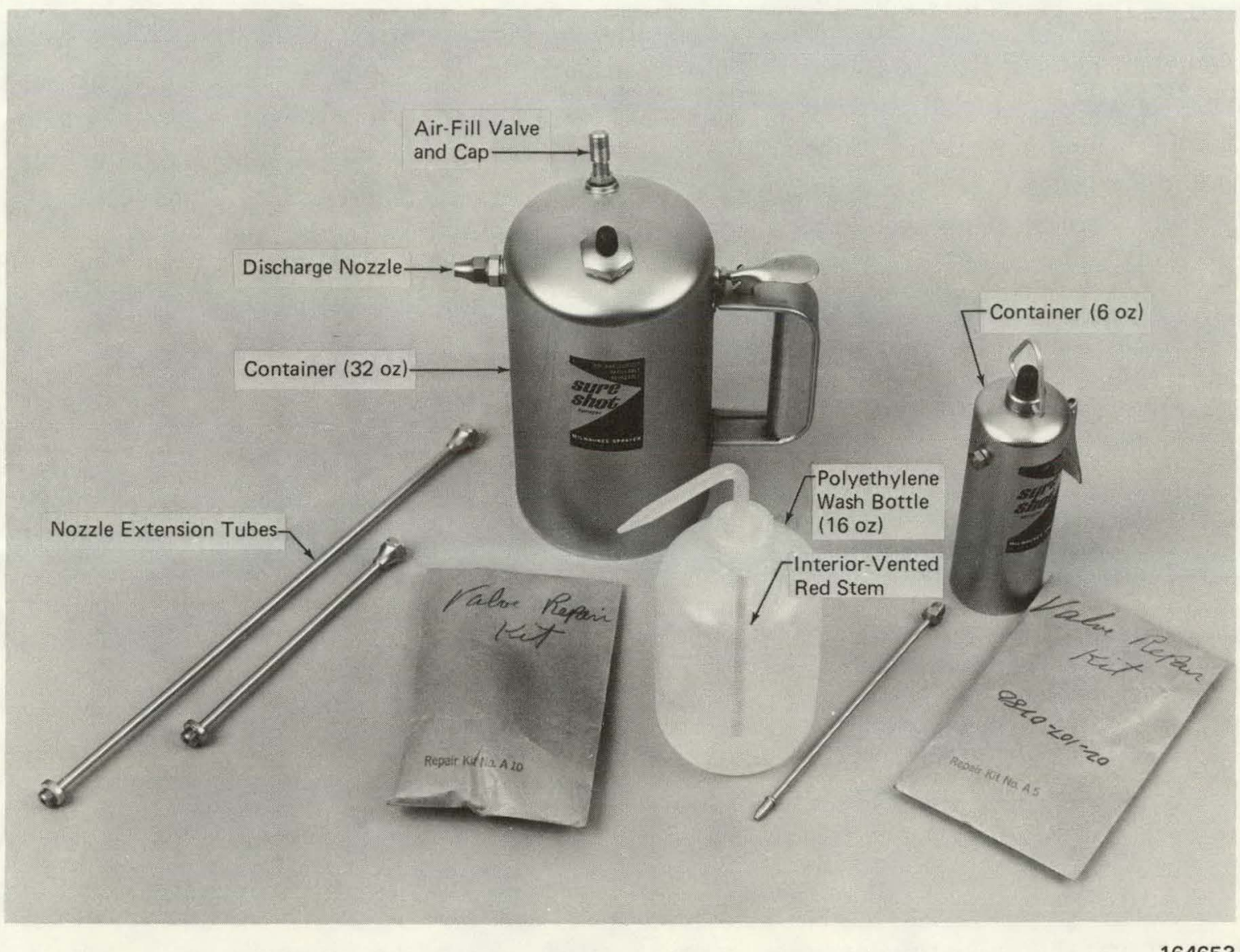

Figure 2. APPROVED FLAMMABLE-LIQUID DISPENSING CONTAINERS MADE OF CHROME-PLATED BRASS.

polyethylene wash bottle for size comparison. The approved container is rigid and is constructed of brass with a chrome-plated exterior. It is available in a large (32-fluid-ounce) size and a smaller (6-fluid-ounce) size. After placing the proper quantity of flammable liquid in the container, the fill cap is tightened and the container is then pressurized with instrument air or inert gas, through an automative fill-type valve, to $40 \mathrm{psig}$. Although these containers were designed and tested to withstand a 1000-psig burst pressure, their use at the Y-12 Plant was discontinued because: (1) they are relatively costly, (2) a warning label that said:"Do Not Use Ammonium Hydroxide or Ammonia" had to be affixed to each container because of adverse reaction with the brass interior, and (3) the container usually remained at its 40-psig loading pressure unless the pressure was dissipated daily. This tixed pressure 
represented a safety hazard since the liquid contents could be discharged accidentally when stored in this pressurized condition.

In a more recent DOE appraisal of fire protection at the $\mathrm{Y}-12$ Plant, ${ }^{2}$ the use of polyethylene plastic wash bottles was approved with the following restrictions: (1) pressure relief must be provided in the cap of the wash bottle, and (2) distribution of the bottles must be restricted, and handling and storage limited in accordance with National Fire Protection Association Standard 45.

Laboratory tests were then made on polyethylene plastic bottles having vent holes with diameters ranging from 0.34 to $1.78 \mathrm{~mm}$ to evaluate drip, leakage, and dispensing effects with various solvents. It was found that if the pressure relief hole in the cap is made large in diameter there is a greater tendency for the interior liquid contents to leak out of the hole should the bottle ever be knocked over on its side. The characteristics of some common laboratory solvents that were evaluated in these tests are listed in Table 1.

Table 1

PHYSICAL PROPERTIES OF SOME COMMON LABORATORY SOLVENTS USED IN WASH BOTTLES

\begin{tabular}{lccc}
\hline \multicolumn{1}{c}{ Solvent } & $\begin{array}{c}\text { Vapor Pressure } \\
(\mathrm{mm} \mathrm{Hg})\end{array}$ & $\begin{array}{c}\text { Flash Point } \\
\left({ }^{\circ} \mathrm{C}\right)\end{array}$ & $\begin{array}{c}\text { Specific } \\
\text { Gravity }(1)\end{array}$ \\
\hline Acetone & 186 & -16.7 & 0.79 \\
Methyl Alcohol & 96 & 15.5 & 0.79 \\
Ethyl Alcohol & 78 & 12.7 & 0.80 \\
Perchloroethylene & 15 & Nonflammable & 1.58 \\
Distilled Water & 17.5 & Nonflammable & 1.00 \\
Trichlorotrifluoroethane (Freon-113) & - & Nonflammable & 1.42 \\
Isopropyl Alcohol & 33 & 22 & 079 \\
Methyl Ethyl Ketonc & 71.2 & 1.5 & 0.81 \\
Methyl Isobutyl Ketone & 16 & 22 & 0.80 \\
n- Hexane & $\sim 100$ & $<-10$ & 0.7 \\
\hline
\end{tabular}

(1) At $20^{\circ} \mathrm{C}$.

It was found that polyethylene wash bottles that were vented with a 0.63-mm-diameter hole in the cap provided the best dispensing action of the liquid contents, but did not prevent leakage of the solvent from the hole when the bottle was laid on its side rather than in a normal vertical position. By locating this $0.63-\mathrm{mm}$-diameter hole just below the cap, leakage of the solvent through the cap was prevented, but an intermittent squirting action (from entrained air) resulted when dispensing the liquid by squeezing the bottle. It was believed that this intermittent flow of solvent would not be objectionable for most Y-12 Plant applications.

A second 0.63 -inch-diameter hole was drilled at the bottom of the dispensing tube 0.5 inch from the end) so that no upside-down insertion of the removable dispensing tube into the screw cap holder could be made. 
Four dozen wash bottles vented with 0.63-mm-diameter holes in the dispensing tube, as illustrated in Figure 3, were made up for trial evaluation with various solvents at various laboratory locations throughout the $\mathrm{Y}-12$ Plant. All users reported that these bottles performed satisfactorily. The Y-12 Plant has recently stocked 6000 vented, red-pigmented polyethylene dispensing tubes in the Stores supply system for Plant usage on flammable solvent wash bottles.

The use of red-pigmented disperising tubes on wash bottles containing flammable solvents will serve to differentiate and help to identify these solvents from nonflammable solvents. Bottles for nonflammable liquids will be fitted with vented, nonpigmented polyethylene dispensing tubes.

Another problem associated with the use

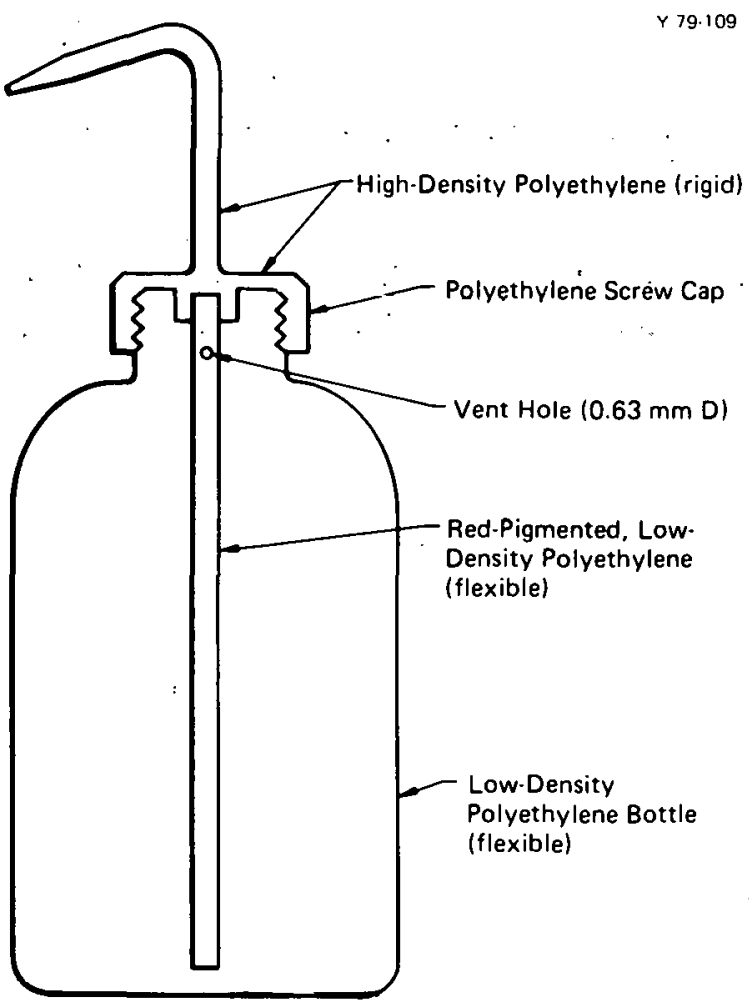

Figure 3. STEM-VENTED POLYETHYLENE SOLVENTDISPENSING BOTTLE. of vented polyethylene wash bottles is that of marking or labeling the containers so as to identify the liquid contents. Four different types of marking or labeling of polyethylene wash bottles that are in current use at the $\mathrm{Y}-12$ Plant are shown in Figure 1. These are:

1. Stenciled aluminum shoulder label (Bottle 2).

2. Stenciled metal neck label (Bottle 6).

3. Ink-printed polyethylene (Bottle 7).

4. Flexible polyethylene belly-band label (Bottles 4 and 5).

Currently, the use of flexible, imprinted, polyethylene "belly-band" labels (b) appears to be the most acceptable. The use of adhesive-backed tape or marking pens with ink is unsuitable as the solvents usually dissolve the adhesive or ink.

(b) A product of Bell-Art Products Company, Pequannor.k, New Jersey. 


\section{REFERENCES}

1. Evans, G. W.; Personal Communication; Oak Ridge Y-12 Plant, Oak. Ridge, Tennessee; 1976.

2. Hickman, H.D.; Semianniual Fire Protection Appraisal of the Y-12 Plant; Energy Research and Development Administration, Oak Ridge, Tennessee; June 25, 1976. 


\section{Distribution}

Department of Energy - Oak Ridge

Hickman, H. D.

Leed, R. E.

Zachry, D. S., Jr

Lawrence Livermore Laboratory

NeIson, W. E.

Los Alamos Scientific Laboratory

Hoyt, H. C.

Oak Ridge Gaseous Diffusion Plant

Bailey, B. I. V.

Stief, S. S.

Wilcox. W. J., Jr

Oak Ridge National Laboratory

Davis, D. M.

Weir, J. R., Jr

\section{Oak Ridge Y-12 Plant}

Armstrong, R. C.

Briscoe, O.W.

Burditt, R. B:

Cuddy, L. M.

DeMonbrun, J. R.

Dodson,W. H./Googin, J. M.

Duggan, H. G.

Foulk, D. L.

Fraser, R. J.

Johnson, C. E.

Jones, F. W.

Keith. A.

Kite, H. T.

Marrow, G. B.

Mason, D. L.

McLendon, J. D.

Phillips, L. R.

Schmitt, C. R. (5)

Smith, H. F., Jr

Smith, R. D.
Sykes. J. B.

Tewes, W. E.

Valentine, C. K.

White, J. E. (5)

Whitehead, H. D. (5)

Y.12 Central Files (master copy)

$Y-12$ Central Files (route copy)

$Y-12$ Central Files $(Y-12 R C)$

$Y-12$ Central Files (5)

Paducah Gaseous Diffusion Plant

Bewley, H. D.

Coltharp, H. G.

Union Carbide Corporation - New York

Tinsley. S. W. 